\title{
A preliminary tectonic fabric chart of the Indian Ocean
}

\author{
JEAN-YVES ROYER ${ }^{1}$, JOHN G SCLATER ${ }^{1,2}$ \\ and DAVID T SANDWELL ${ }^{1}$ \\ ${ }^{1}$ Institute for Geophysics, The University of Texas at Austin 8701 MOPAC Blvd, Austin, \\ TX 78759-8345, USA \\ ${ }^{2}$ Department of Geological Sciences, The University of Texas at Austin, Austin, TX 78713, \\ USA
}

\begin{abstract}
We present a preliminary tectonic chart of the Indian Ocean based on a joint compilation of bathymetric data, magnetic anomaly data and Geosat altimetry data. Satellite altimeters such as Geosat map the topography of the equipotential sea surface or marine geoid. Our interpretation of the GEOSAT data is based on an analysis of the first derivative of the geoid profiles (i.e. deflection of the vertical profiles). Because of the high correlation between the vertical deflection (at wavelength $<200 \mathrm{~km}$ ) and the seafloor topography, the Geosat profiles can be used to delineate accurately numerous tectonic features of the ocean floor such as fracture zones, seamounts and spreading ridges. The lineations in the Geosat data are compared with bathymetric data and combined with magnetic anomaly identifications to produce a tectonic fabric chart of the Indian Ocean floor.
\end{abstract}

Keywords. Indian Ocean; GEOSAT altimeter; deflection of the vertical; tectonic fabric chart.

\section{Introduction}

During the past few years, as a result of development of remote sensing and data imaging techniques, better resolution and coverage have permitted the upgrading of the tectonic picture of the ocean floor. In the Indian Ocean, one may examine the development of this improved resolution by comparing the successive tectonic charts produced by Heezen and Tharp (1965) and Udintsev et al (1975), and the bathymetric charts of the GEBCO series (1975-1982) with the recent chart of the gravity field by Haxby (1985). Satellite altimeters (GEOS-3, SEASAT, GEOSAT) map the topography of the equipotential sea surface (marine geoid). Due to the uniform coverage of the satellite ground tracks and the excellent correlation between the short wavelengths $(20-200 \mathrm{~km})$ of the geoid signal with the topographic gradient of the ocean floor, the satellite altimeter data bring a wealth of rigorously comparable information bearing on the morphology of the seafloor, especially in the remote inhospitable and hence poorly charted southern oceans. There, in particular, previously unrecognized tectonic elements, specifically fracture zones and seamounts, have been delineated or verified (e.g. Lazarewicz and Schwank 1982; Sandwell 1984; Haxby 1985; Sandwell and McAdoo 1988).

Recently, Gahagan et al (1988) have used the anomalies and lineations in plots of the deflection of the vertical from SEASAT data to portray a preliminary fabric chart of the ocean floor. In this paper, we expand upon this approach by presenting first, plots of the actual deflection of the vertical data along tracks, second, identifying lineations in these plots and finally, comparing these lineations with bathymetric 
features and magnetic anomaly identifications in order to construct a preliminary tectonic fabric map of the ocean floor. This work is based primarily on the GEOSAT data which we combine with the SEASAT data set. This analysis reveals new features on the seafloor at the southerly latitudes that are related to the early phase evolution of the Indian Ocean. Recently-refined portrayals of tectonic fabrics of the seafloor provide exceptionally good constraints for plate tectonic reconstructions far beyond those available to the pioneer modellers of the evolution of the Indian Ocean (e.g. Fisher et al 1971; McKenzie and Sclater 1971; Sclater and Fisher 1974; Norton and Sclater 1979; Partriat 1987). In fact, problems with previous reconstruction models have generally arisen in areas where either the fracture zone lineations or the magnetic lineations were poorly established through lack of shipborne coverage. Hence, the joint compilation of magnetic anomalies and fracture zone lineations from closelyspaced altimetry traverses has proved to be a very powerful approach as it allows us to revise and improve our understanding of the tectonic history of the ocean floor (e.g. Royer et al 1988; Royer and Sandwell 1989; Mayes et al 1989).

\section{A tectonic history of the Indian Ocean}

The Indian Ocean floor (figure 1) is characterized by a system of three active spreading ridges that now separates four major fragments of the former supercontinent Gondwana: Africa, India, Australia and Antarctica. The northern branch of this ridge system rises in the Gulf of Aden, separating Africa from Arabia, and continues along the Carlsberg Ridge and the Central Indian Ridge which separates Africa from India. At $25^{\circ} \mathrm{S}, 70^{\circ} \mathrm{E}$, the Central Indian Ridge intersects the two other branches, the Southwest Indian Ridge that extends between Africa and Antarctica towards the South Atlantic, and the Southeast Indian Ridge that extends towards the South Pacific between Antarctica and India, and Antarctica and Australia. Numerous ridges and plateaus of intermediate depth, which may be taken to characterize the Indian Ocean, appear on either sides of the spreading ridges. The size, number and distribution of these elevations have raised many questions about their nature and origin as well as their role in the continuing development of the Indian Ocean. From east to west, they are the South Tasman Rise, the plateaus off western Australia (Naturaliste, Cuvier, Wallaby, Exmouth), Broken Ridge and the Kerguelen Plateau, Ninetyeast Ridge, Chagos-Laccadive Ridge and the Mascarene Plateau, the Chain and Murray Ridges, Madagascar Plateau, Del Cano Rise, Crozet Plateau, Conrad Rise, Gunnerus Ridge, Mozambique Ridge, Astrid Ridge, Agulhas Plateau and finally Maud Rise (figure 1).

According to interpretations of the seafloor magnetic anomaly pattern as identified in the Indian Ocean, the major basins lying between the spreading ridges, the continental margins and the submarine ridges evolved during three main periods. From the breakup of Gondwana in the Late Jurassic to the mid-Cretaceous, Africa separated from Madagascar and Antarctica, creating respectively the western Somali Basin (Ségoufin and Patriat 1980; Rabinowitz et al 1983; Coffin and Rabinowitz 1987; Cochran 1988), the symmetric Mozambique Basin (Ségoufin 1978; Simpson et al 1979) and the basin off Dronning Maud Land, Antarctica (Bergh 1977, 1987). During the same time period, Indian and Madagascar separated from Australia and Antarctica, creating the Mesozoic basins along the western margin of Australia (Markl 1974, 


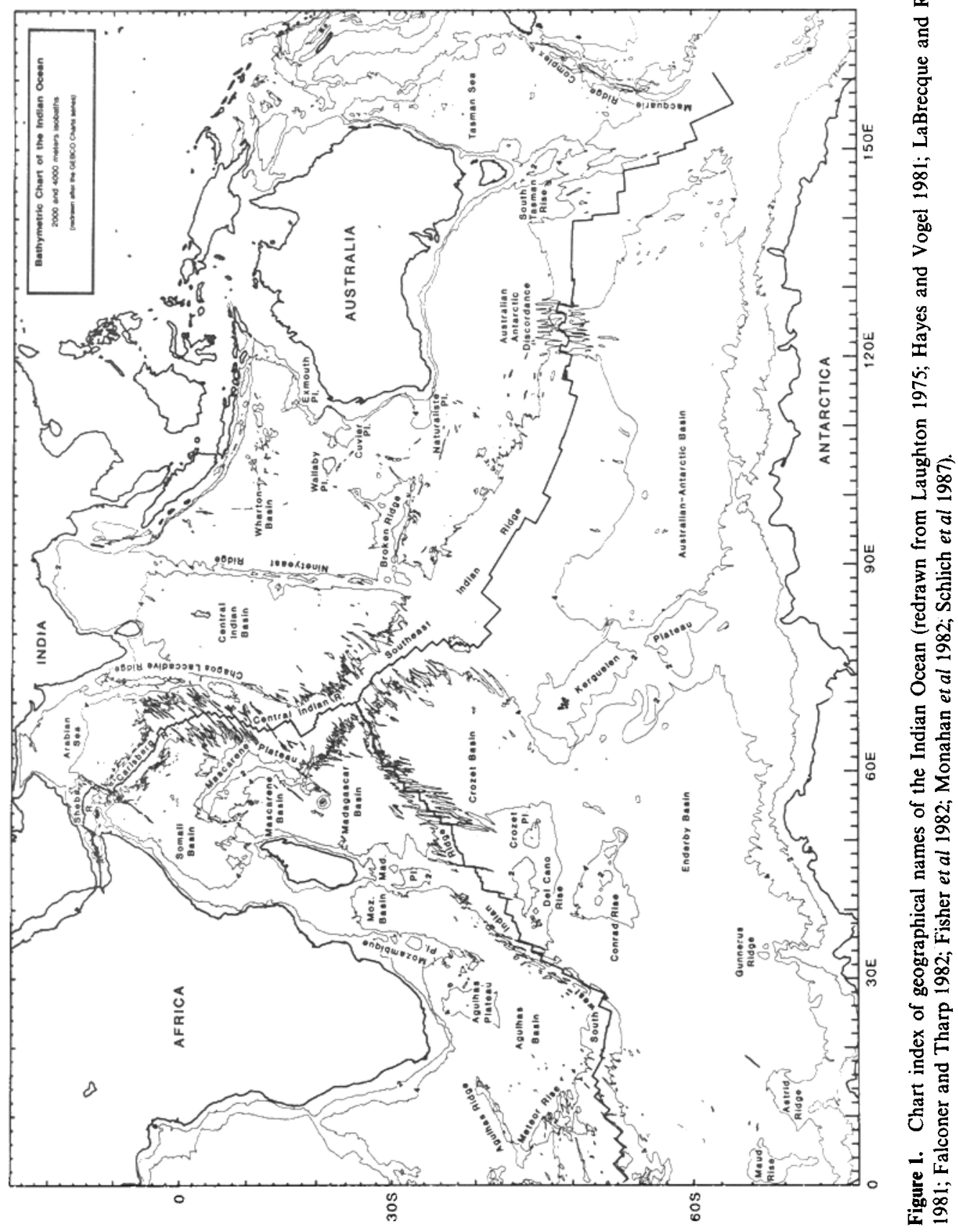


1978; Larson et al 1979; Veevers et al 1985). From the mid-Cretaceous to the Middle Eocene, the major motion resulted in the rapid northward drift of India towards Asia. Most of the floor of the Indian Ocean was created during this phase: the basins between Africa-Madagascar and Antarctica (Bergh and Norton 1976; Patriat 1979; LaBrecque and Hayes 1979; Sclater et al 1981; Fisher and Sclater 1983), the Madagascar and the Mascarene Basins, the eastern Somali Basin and the Arabian Sea between Africa-Madagascar and India (McKenzie and Sclater 1971; Whitmarsh 1974; Schlich 1975, 1982), the mirrored Central Indian Basin and Crozet Basin between India and Antarctica (McKenzie and Sclater 1971; Sclater and Fisher 1974; Schlich 1975, 1982) and the Wharton Basin between India and Australia (Sclater and Fisher 1974; Liu et al 1983). In addition, during this period, Australia and Antarctica commenced to separate (Cande and Mutter 1982). The latest period in the evolution of the Indian Ocean started with a major reorganisation of the spreading centres, consequent to the collision of India with Asia in the Middle Eocene. Seafloor spreading ceased in the Wharton Basin while major changes in the direction and rate of spreading occurred in the Central Indian Basin, the Crozet Basin, the Madagascar Basin, the eastern Somali Basin and the Arabian Sea. The new configuration of the spreading ridges corresponds to the present-day ridge system. During this phase, the AustralianAntarctic Basin (Weissel and Hayes 1972), the southern Central Indian Basin (Sclater et al 1976a) and the northern Crozet Basin (Schlich 1975) were created. Also, the Mascarene Plateau and the Chagos-Laccadive Ridge separated (Fisher et al 1971; McKenzie and Sclater 1971), and the Gulf of Aden opened (Laughton et al 1970). Because of the differential motion along the Central Indian Ridge and the Southeast Indian Ridge, the Southwest Indian Ridge propagated rapidly towards the east (Tapscott et al 1980; Sclater et al 1981; Patriat 1987).

\section{Analysis of the altimetry data: Lineations in the deflection of the vertical charts}

The SEASAT satellite, launched by NASA in 1978, used a radar altimeter to make precise measurements (Tapley et al 1982) of the sea-surface or geoid height $(\sim 1.0 \mathrm{~m})$ over most of the world's oceans. Unfortunately, the SEASAT mission failed after a few months, and almost no data were recovered from the areas south of $62^{\circ} \mathrm{S}$ because of the ice-coverage around Antarctica at the time that SEASAT operated. In March 1985, the US Navy launched the GEOSAT altimeter in order to map the marine geoid to a high spatial resolution on a global basis. Only the data from the Exact Repeat Mission, started in November 1987, which duplicated the 17 days SEASAT repeat orbits, have yet been unclassified. However, because the ground track spacing ( $\sim 164 \mathrm{~km}$ at the Equator) decreases at the high latitudes, and because GEOSAT operated during the Austral ice-free summer, the information from the high southerly latitudes, between $60^{\circ} \mathrm{S}$ and $72^{\circ} \mathrm{S}$, is exceptionally good. In this study, we use mainly the GEOSAT data. The accuracy is about 3 times better than for the SEASAT (Sandwell and McAdoo 1988) and we improve this accuracy and data recovery along tracks by stacking 22 GEOSAT repeat cycles. For wavelengths greater than $20 \mathrm{~km}$, the rms noise level of the GEOSAT data is about 1 to $2 \mathrm{mGals}$. However, in order to take advantage of the better density of the SEASAT data north of $60^{\circ} \mathrm{S}$, we combine both SEASAT and GEOSAT data sets when the amplitudes of the SEASAT signal were above the noise level. 
To enhance the short wavelengths of the marine geoid signal, it is more appropriate to use the deflection of the vertical which is the first derivative of the geoid along the track. Deflection of the vertical, expressed in microradians, measures the variation of the horizontal gravity field. One microradian ( $\mu \mathrm{rad})$ is roughly equivalent to a horizontal variation in gravity of one milligal ( $\mathrm{mGal}$ ). Figures 2 and 3 display the deflection of the vertical plotted along respectively the descending and ascending satellite ground tracks. Vertical bars along tracks are spaced every 4 data points ( $\sim 14 \mathrm{~km}$ apart). Amplitudes are positive to the north. The scale of amplitude is 20 $\mu \mathrm{rad} /$ degree of longitude; however when greater than $30 \mu \mathrm{rad}$, the amplitudes are reduced through an arctangent function. Long wavelength $(>4000 \mathrm{~km})$ and short wavelength noise $(<20 \mathrm{~km})$ have been removed from each pass using the procedure described by Sandwell and McAdoo (1988).

Figure $4 \mathrm{~A}$ through $4 \mathrm{~J}$ display a series of different interpretations of the deflection of the vertical signal. In a tectonic fabric chart, we are mostly interested in the lineated features such as fracture zones, spreading ridges, linear troughs, ridges or plateaus, and trenches. Depending on their extension, most of these features have a reproducible signature on a set of parallel profiles, which make them easy to identify. The signature of a fracture zone will vary according to the spreading rate and the age offset (figures $4 \mathrm{~A}$ and $4 \mathrm{~B}$ ). Depending on the direction of the satellite and the orientation of the tectonic feature relative to the satellite ground track, the signature of a tectonic feature can be identical or reversed on the ascending or descending data sets. As a rule of thumb, topographic features oriented north-south will have same signatures; in the case of a fracture zone (figure $4 \mathrm{C}$ ), both the ascending and descending profiles cross the topographic (age) offset from the same side. East-west oriented features will have reversed signatures; in figure $4 \mathrm{D}$, ascending and descending profiles approach the fracture zone from opposite sides. Because the age offset reverses at the midpoint of the transform segment of a fracture zone, the signature of a fracture zone is symmetric relative to the fracture zone axis and of opposite sign on either side of this point (figure 4E). Finally, the spacing of parallel fracture zones is also an important factor; the combined effects of parallel topographic (age) offsets may produce a large signal where the signal produced by each individual fracture zone cannot be identified (e.g. Prince Edward FZ area along the Southwest Indian Ridge). The signature of a spreading ridge axis depends on the spreading rates as does the topography (figures $4 \mathrm{~F}$ and $4 \mathrm{G}$ ). Seamounts have a typical signature (figure $4 \mathrm{H}$ ) recognizable at isolated, sharp and narrow positive and negative picks of equal amplitude. Trenches (figure 4I) are characterized by a succession of positive and negative picks related to the flexure of the lithosphere ahead of the trench and to the trench itself. Continental rise (figure $4 \mathrm{~J}$ ) and linear offsets in the oceanic basement are also clearly identifiable. Finally, aseismic ridges and plateaus are clearly visible, but, depending on their width and height relative to the adjacent basins, they are difficult to chart. The deflection of the vertical charts of the Indian Ocean (figures 2 and 3) provides examples for each type of feature. We have traced lineations in these charts by correlating respectively peaks and troughs (i.e. steepest horizontal gradient of the gravity) in the deflection of the vertical plots, on both the ascending and descending passes. Figure 5 summarizes our interpretation of the lineations in the deflection of the vertical plots. We have abbreviated the name of this chart to deflection of the vertical lineations. Symbols show the actual location of the data points and lines, the lineations. We deliberately have not represented the peaks and troughs associated with large topographic features 


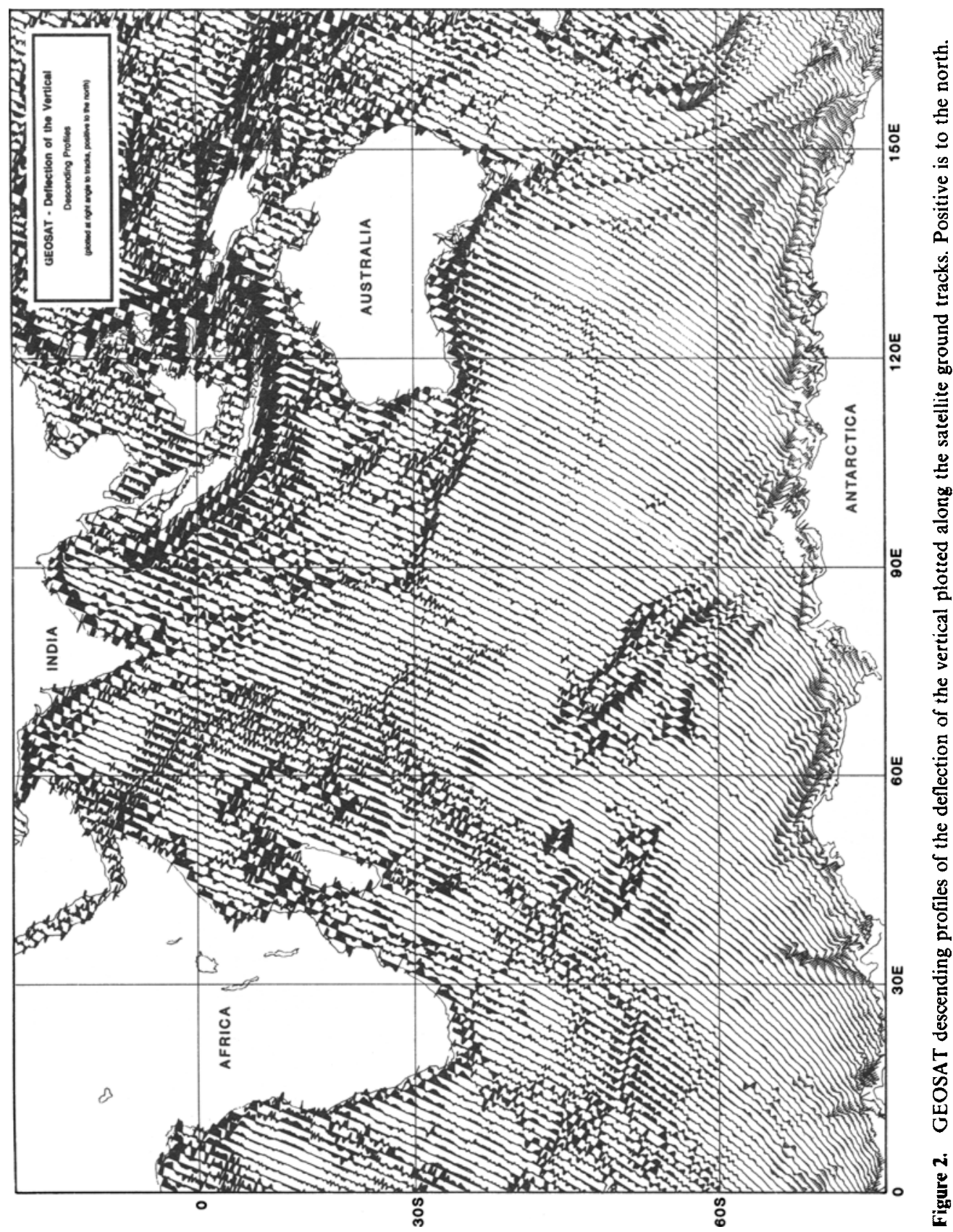




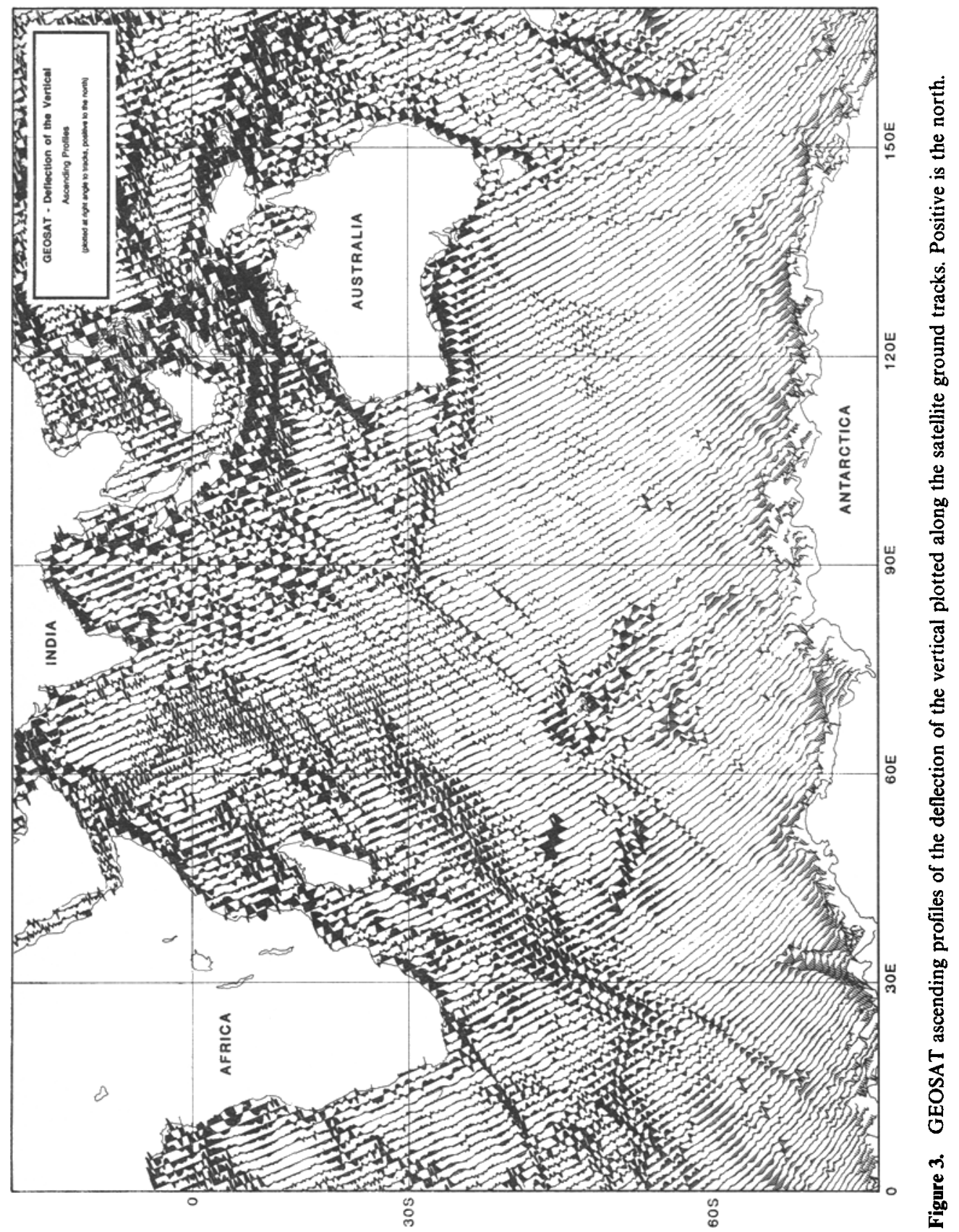



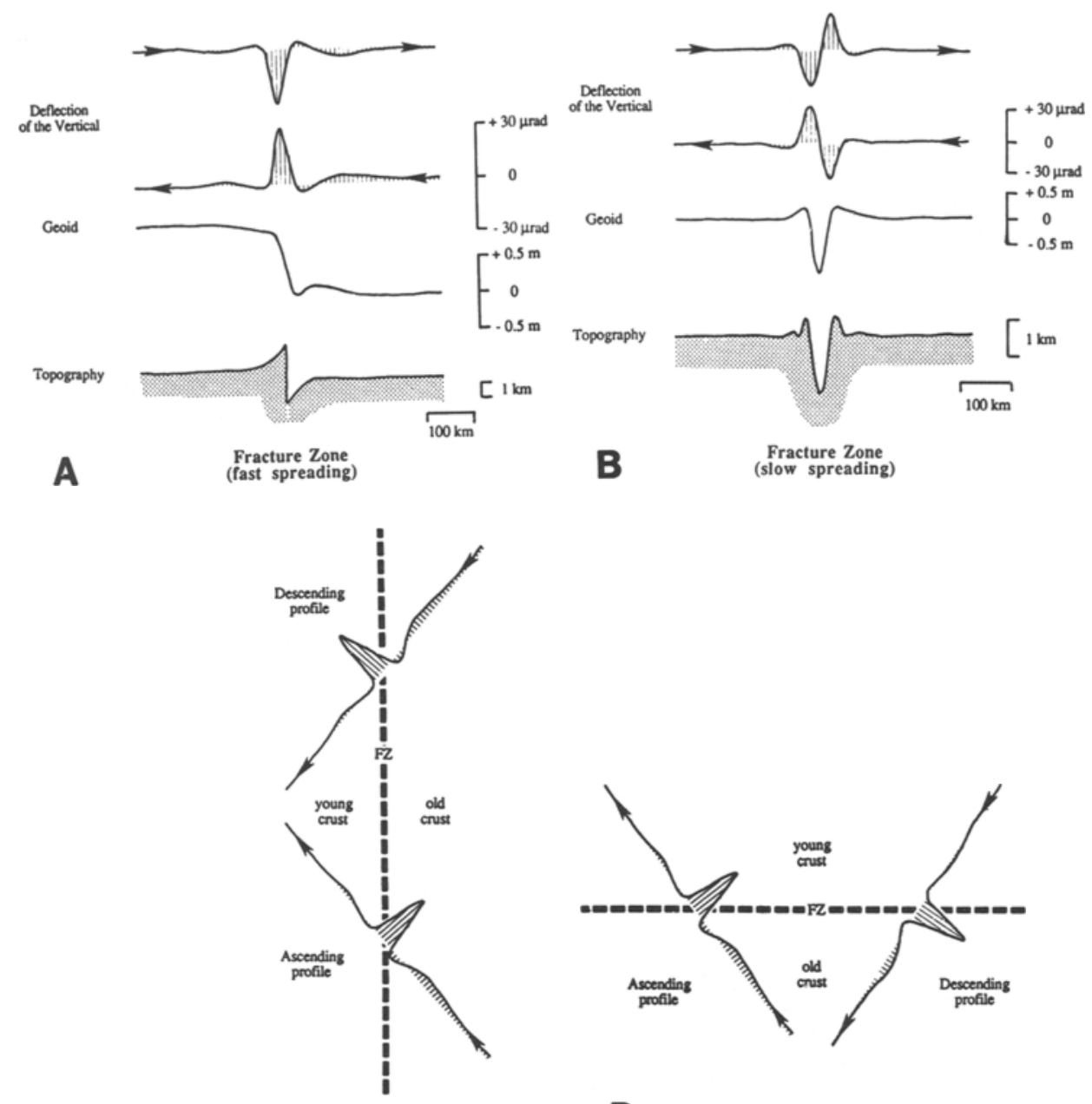

Corth-South Fracture Zone

D East-West Fracture Zone
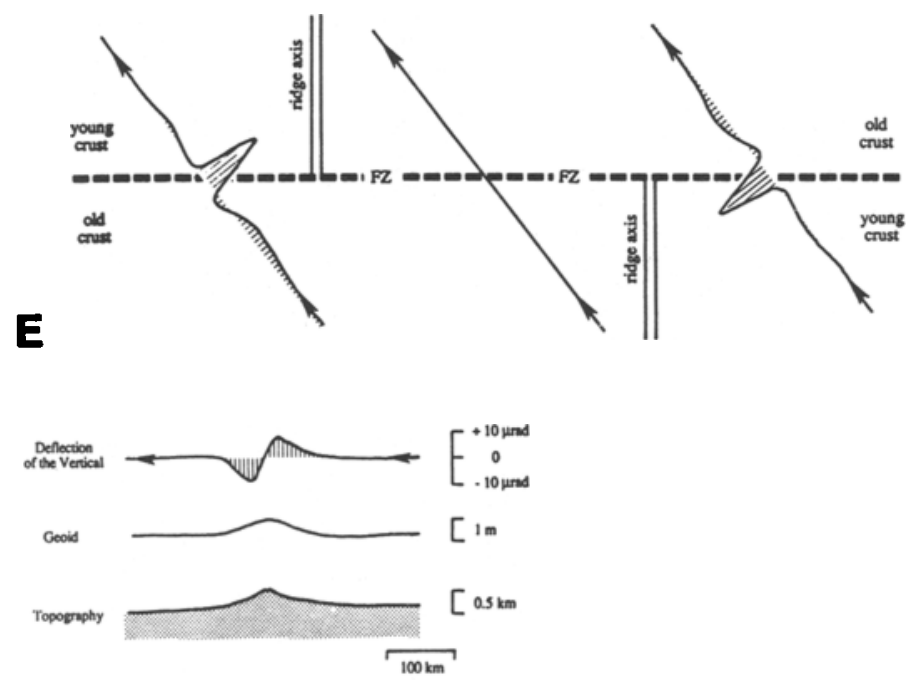

F $\quad \begin{gathered}\text { Spreading Ridge } \\ \text { (last spreading) }\end{gathered}$ 


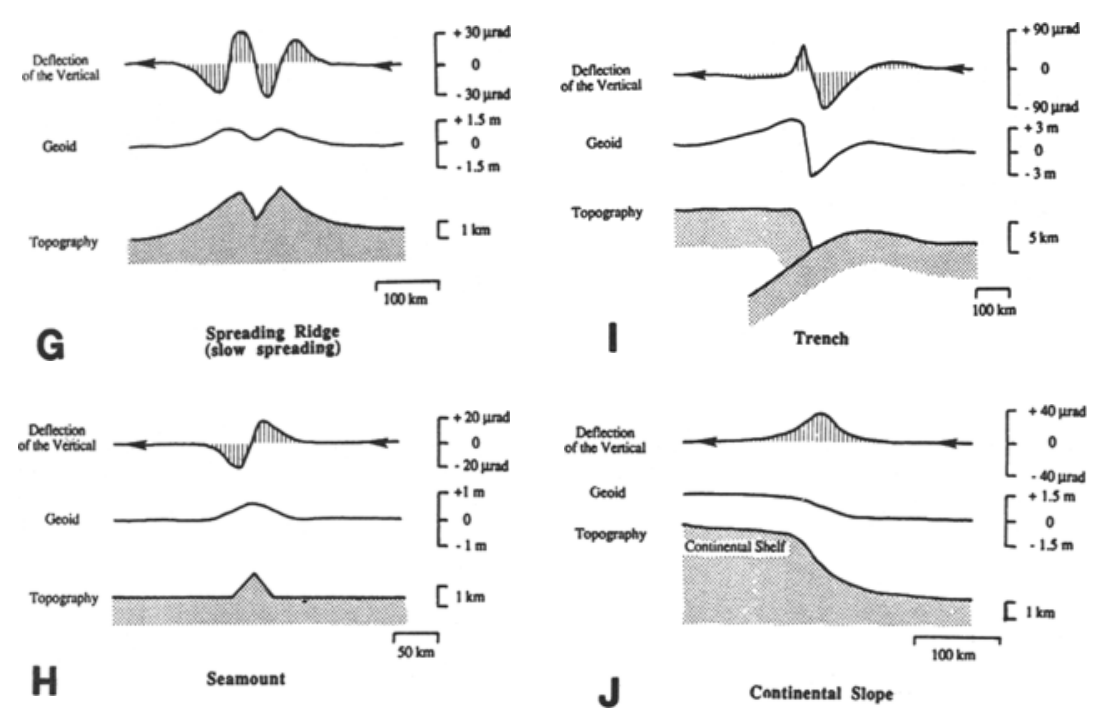

Figure 4. Schematic signatures of the geold and the deflection of the vertical (horizontal derivative of the gravity field) across some tectonic features of the ocean floor: (A), (B) Fracture zones. Since the deflection of the vertical is the horizontal derivative of the geoid along the satellite ground track, the sign of the signal changes with the direction of the satellite. (C), (D) Deflection of the vertical plotted at right angle of the subsatellite tracks. Positive is to the north (top of page). Descending and ascending profiles will have an identical signature across a north-south oriented fracture zone while they will show an opposite signature across an east-west oriented fracture zone. (E) Variation of the deflection of the vertical signal along a fracture zone (same convention as for $\mathrm{C}$ and $\mathrm{D}$ ). The signal reverses at the midpoint of the transform segment of the fracture zone as does the age offet. $(F),(G)$ Deflection of the vertical signature above spreading ridge axes. (H) Seamount signatures generally show two sharp positive and negative picks of equal amplitude. (H) Trench (J) Continental rise.

of the ocean flour, outlined in figure 5 by bathymetric contours. Such features are better represented by direct contouring of the gravity field (e.g. Haxby 1985).

\section{Tectonic fabric chart of the Indian Ocean}

The deflection of the vertical plots amplify the short wavelengths of the geoid. Lineations in these charts are in general related to high amplitude short wavelength topographic features such as transform faults, fracture zones, seamounts and other discrete entities on the seafloor. By combining the lineations of the deflection of the vertical charts with transform faults and fracture zones known from topographic and magnetic surveys, it is possible to create an improved tectonic chart of the sea floor. Because of the greater coverage of the satellite data and the ability of the presentation to amplify and extend lineated features both above and below sediment, the resultant signal presents a fabric chart of the igneous basement of the seafloor. We have abbreviated the name of these combined charts to "tectonic fabric charts".

The lineations in the deflection of the vertical charts (figure 5) are documented to varying degrees depending on the characteristics of seafloor spreading in the oceanic basins: spreading rate, paleo-direction of spreading relative to the satellite ground 
tracks and the age offsets across the fracture zones. The interpretation of the deflection of the vertical charts brings new information mainly on the southerly latitudes around Antarctica regarding the early phase of seafloor spreading between Africa and Antarctica during the Late Jurassic up to the Late Cretaceous, and between Antarctica and Australia during the Middle Eocene. In addition, due to the uniform coverage of the satellite profiles, the fracture zones are generally better sampled and their pattern better defined on the deflection of the vertical charts than on tectonic charts based on shipborne data. This is for instance the case along the Central Indian Ridge, or between Broken Ridge and the Kerguelen Plateau, or between Tasmania and Antarctica. Except for this latter area, most of the fracture zones in the Indian Ocean are oblique or perpendicular to the ascending satellite tracks and parallel or sub-parallel to the descending tracks. Therefore, they are more visible on the ascending passes (figure 3) than on the descending passes (figure 2), while the opposite occurs for the Indian Ocean spreading ridges. However, in some areas such as the Australian-Antarctic Discordance where the fracture zones are oriented north-south and the ridge axes east-west, both data sets are complementary.

In regard to the evolution of the Indian Ocean, the best documented period corresponds to the latest and most recent phase of seafloor spreading that started after the general reorganization of the plate boundaries in the Middle Eocene. Along the Sheba, Carlsberg and Central Indian Ridges, the fracture zones strike N50 ${ }^{\circ}$ to N60 ${ }^{\circ}$ E. From the northwest to the southeast, the main fracture zones are the Alula-Fartak FZ $\left(13^{\circ} \mathrm{N}, 51^{\circ} \mathrm{E}\right)$ at the mouth of the Gulf of Aden, the Owen FZ $\left(12^{\circ} \mathrm{N}\right.$, $56^{\circ} \mathrm{E}$ ) separating the Sheba Ridge from the Carlsberg Ridge, the fracture zone at $3^{\circ} \mathrm{N}$, the Mahabiss FZ $\left(3^{\circ} \mathrm{S}\right)$, the Sealark FZ $\left(4^{\circ} \mathrm{S}\right)$, the Vitiaz FZ $\left(8^{\circ} \mathrm{S}\right)$, the Vema FZ $\left(11^{\circ} \mathrm{S}\right)$, the Argo FZ $\left(14^{\circ} \mathrm{S}\right)$, the Marie Celeste FZ $\left(17^{\circ} \mathrm{S}\right)$ and the Egeria FZ $\left(20^{\circ} \mathrm{S}\right)$ which lies east of the Rodrigues Ridge. Except for the Alula-Fartak FZ and the fracture zone at $3^{\circ} \mathrm{N}$, all the transform offsets are left-lateral. The largest transform offsets are located along the Alula-Fartak FZ $(200 \mathrm{~km})$, the Owen FZ $(300 \mathrm{~km})$, the Vema FZ $(200 \mathrm{~km})$ and the Marie Celeste FZ $(220 \mathrm{~km})$. Along the Southwest Indian Ridge, the orientation of the fracture zones varies progressively from $N 45^{\circ} \mathrm{E}$ in the vicinity of the Bouvet Triple Junction $\left(55^{\circ} \mathrm{S}, 1^{\circ} \mathrm{W}\right)$ to north-south, west of the Indian Ocean triple junction $\left(25^{\circ} \mathrm{S}, 70^{\circ} \mathrm{E}\right)$. From west to east, they are Bouvet $\mathrm{FZ}\left(2^{\circ} \mathrm{E}\right)$, Moshesh FZ ( $\left.5^{\circ} \mathrm{E}\right)$, Islas Orcadas FZ $\left(6^{\circ} \mathrm{E}\right)$, Shaka FZ associated with the Shaka Ridge $\left(8^{\circ} \mathrm{E}\right)$, Dingaan FZ $\left(12^{\circ} \mathrm{E}\right)$, Mandela FZ $\left(15^{\circ} \mathrm{E}\right)$, Du Toit FZ $\left(26^{\circ} \mathrm{E}\right)$, the Andrew Bain FZ complex $\left(28^{\circ} \mathrm{E}\right)$, Prince Edward FZ $\left(35^{\circ} \mathrm{E}\right)$, Discovery II FZ $\left(43^{\circ} \mathrm{E}\right)$, Indomed FZ $\left(46^{\circ} \mathrm{E}\right)$, Gallieni FZ $\left(52^{\circ} \mathrm{E}\right)$, the Atlantis II FZ $\left(58^{\circ} \mathrm{E}\right)$ and the Melville FZ $\left(61^{\circ} \mathrm{E}\right)$. The transform offsets are right-lateral and generally important $(100$ to $200 \mathrm{~km})$ for all these fracture zones; the major offset $(800 \mathrm{~km})$ along the Southwest Indian Ridge axis occurs between Bain FZ and Prince Edward FZ $\left(28^{\circ} \mathrm{E}\right.$ to $\left.35^{\circ} \mathrm{E}\right)$. Finally, along the Southeast Indian Ridge, the fracture zonc trends, oriented $\mathrm{N} 45^{\circ} \mathrm{E}$ in the vicinity of the Indian Ocean triple junction, shift progressively to $\mathrm{N} 15^{\circ} \mathrm{E}-\mathrm{N} 10^{\circ} \mathrm{E}$ between Australia and Antarctica, and reach $\mathrm{N} 15^{\circ} \mathrm{W}$ in the vicinity of the Macquarie triple junction $\left(61^{\circ} \mathrm{S}, 162^{\circ} \mathrm{E}\right)$. The major offsets are located along the Amsterdam and $\mathrm{St}$ Paul FZ $\left(78^{\circ} \mathrm{E}\right)$ and along the George V, Tasman and Balleny FZ. The fracture zone pattern between Australia and Antarctica, particularly the prominent fracture zones south of Tasmania that can be traced all the way south into the Antarctic margin, tightly constrain the reconstructions in the Australian-Antarctic Basin since the Middle Eocene (Anomaly 20). Prior to that time and since the initiation of spreading 


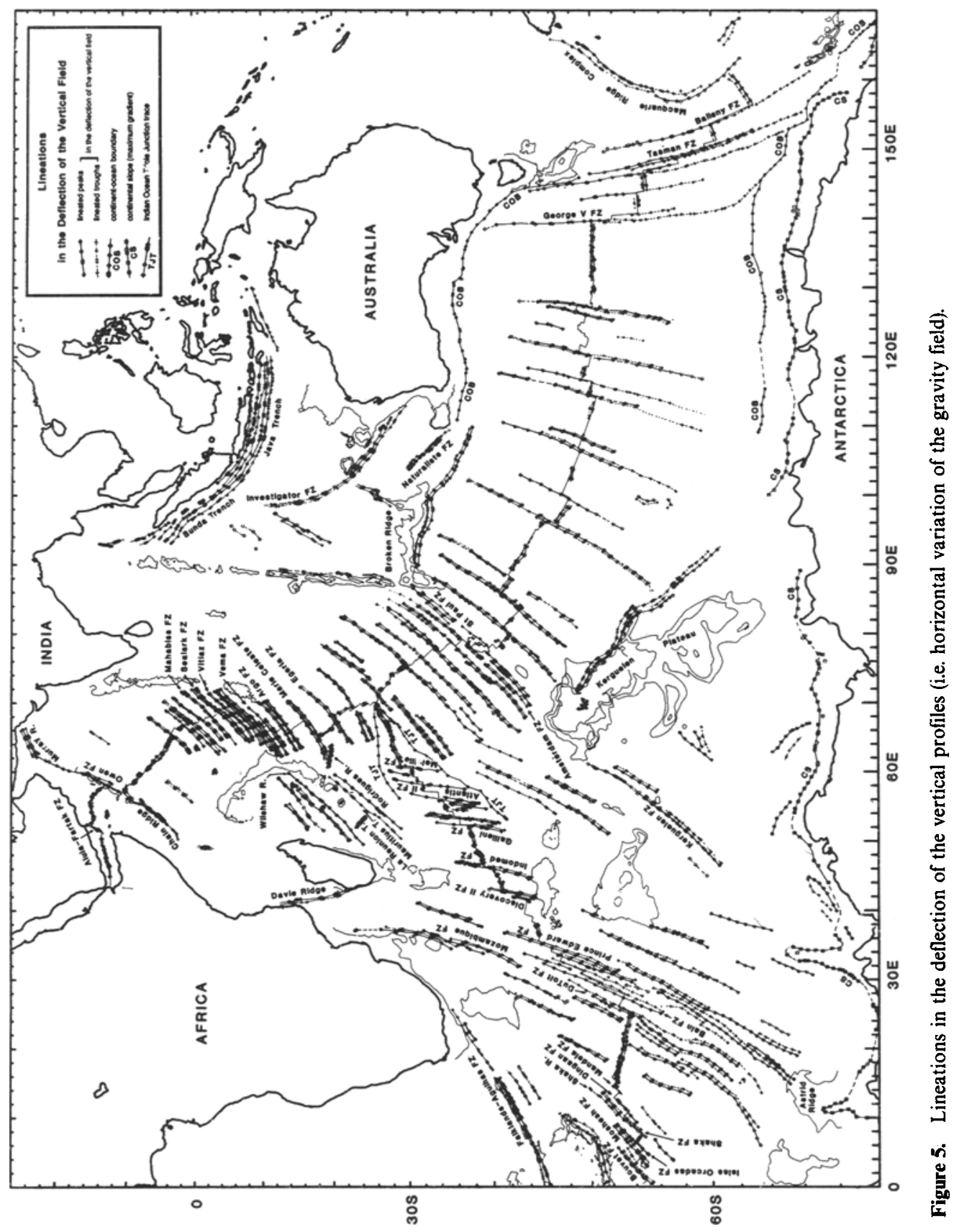


in the Late Cretaceous, seafloor spreading was extremely slow $(0.5 \mathrm{~cm} / \mathrm{a}$; Cande and Mutter 1982) and the magnetic lineations are continuous and parallel to the Australian and Antarctic margins.

The spacing between satellite profiles is generally too large $(160-80 \mathrm{~km})$ to allow an accurate mapping of the mid-oceanic ridge axes. However in several areas, the deflection of the vertical data shows an excellent correlation with the location of the ridge axes deduced from bathymetric and magnetic data. The Sheba Ridge is characterized by a slow spreading rate $(1 \mathrm{~cm} / \mathrm{a}$, Laughton et al 1970) and an axial valley that deepens towards the east. The ridge axis produces a clear signature on the deflection of the vertical signal, as illustrated in figure $4 \mathrm{G}$, that defines two continuous ridge segments separated by the Alula-Fartak FZ. The Carlsberg Ridge has similar characteristics as the Sheba Ridge with spreading rate ranging from 1.2 to $1.3 \mathrm{~cm} / \mathrm{a}$ (Le Pichon and Heirtzler 1968; McKenzie and Sclater 1971) and shows a linear and nearly continuous ridge axis from the Owen FZ to the Equator. The Central Indian Ridge, which runs between the Mascarene Plateau and the Chagos-Laccadive Ridge, is extremely segmented by closely spaced fracture zones. The first ridge segments clearly identifiable out of the geoid signal caused by the fracture zones are located southeast of the Rodrigues Ridge. The spreading rates for this mid-oceanic ridge range from north to south between 1.8 and $2.4 \mathrm{~cm} / \mathrm{a}$ (Fisher et al 1971; Patriat 1987). The Southwest Indian Ridge has a very slow spreading rate (less than $1 \mathrm{~cm} / \mathrm{a}$; Schlich and Patriat 1971a; Sclater et al 1976b, 1981; Patriat 1987) and is expressed by a deep and pronounced inner valley. Several extensive ridge segments are well delineated by the deflection of the vertical data between the Mandela and Du Toit FZ which is the longest segment, east of the Prince Edward FZ, between the Discovery II, Indomed, and Gallieni $\mathrm{FZ}$, and between the Melville FZ and the Indian Ocean triple junction. The Southeast Indian Ridge is the most active of the three Indian mid-oceanic ridges with medium spreading rates increasing from west to east from 3.0 to $3.5 \mathrm{~cm} / \mathrm{a}$ (Schlich and Patriat 1971b; Weissel and Hayes 1972; Schlich 1975; Patriat 1987). Between the Indian Ocean triple junction and the Amsterdam and St Paul FZ, the ridge axis is segmented by several fracture zones and is generally well expressed by an axial valley, while east of the St Paul FZ the ridge segments are long and continuous and expressed by a central rise typical for medium or fast spreading ridges (Weissel and Hayes 1972; Royer and Schlich 1988). The area of the Australian-Antarctic Discordance presents an anomalous topography and fracture zone pattern (Vogt et al 1983). The deflection of the vertical signal along the Southeast Indian Ridge varies from that of figures $4 a$ and $4 b$. The trenches along the Java and Sumatra Islands and south of New Zealand are the second type of present-day plate boundaries that clearly show on the deflection of the vertical data.

The altimetry data add little information on the fabric of the oceanic basins related to the second phase of opening of the Indian Ocean, from the mid-Cretaceous to the Middle Eocene. Only the Murray Ridge and the Chain Ridge, on either sides of the Owen Fracture Zone, document in the Arabian Sea and eastern Somali Basin the drift of India away from the Seychelles and East Africa. Structural directions in the Central Indian Basin and the Wharton Basin (McKenzie and Sclater 1971; Sclater and Fisher 1974), which record the fast northward drift of India relative to Antarctica and Australia, do not show well on the deflection of the vertical data. Their north-south orientation is too close from those of the satellite profiles. In the Wharton Basin, in addition to the Investigator FZ and the eastern scarp of the Ninety east Ridge, a cross grain is apparent, while intraplate deformation within the Central Indian Basin cause 
east-west undulation of the lithosphere that obliterate and obscure the tectonic fabrics (c.g. Weissel et al 1980; Geller et al 1983; Haxby 1985; McAdoo and Sandwell 1985). However, in the conjugate basins, the Madagascar and Crozet Basins, the fracture zone pattern is well recognizable. The most important feature is the Kerguelen Fracture Zone that offset the magnetic lineations 32, 33 and 34 (Schlich 1982; Patriat $1987)$ by more than $800 \mathrm{~km}$. With the GEOSAT data, it becomes clear that this feature does not extend further south than $62^{\circ} \mathrm{S}$, and therefore post-dates the plate boundary reorganization in the mid-Cretaceous. In the Mascarene Basin, part of the extinct spreading system is visible. This system initiated at the time of the break-up between India and Madagascar in the mid-Cretaceous and died in the Paleocene/Early Eocene (chron 31 to 27; Schlich 1982) when the spreading ridge jumped to the north to form the Carlsberg Ridge and subsequently separated India from the Seychelles and the northern Mascarene Plateau. Remnant of the fossil spreading axis can be identified southwest of La Réunion Island (La Réunion Trench), north of the Mauritius Trench extension that forms the limit of the extinct spreading system with the Madagascar Basin. The fossil spreading ridge is offset $400 \mathrm{~km}$ to the north by the Mahanoro $\mathrm{FZ}$ and Wilshaw Ridge complex. Further north, the fracture zone pattern becomes unclear. Finally, the most interesting information related to mid-Cretaceous/Middle-Eocene time span concerns the relative motion of Africa and Antarctica. A clear set of parallel fracture zones can be defined between the Agulhas Plateau and the Maud Rise and Astrid Ridge, off Antarctica. At $48^{\circ} \mathrm{S}$ on the northern flank, and at $58^{\circ} \mathrm{S}$, on the southern flank, there is a clear disruption of the fracture zone pattern which is shifted, by 50 to $100 \mathrm{~km}$, to the east or to the west, respectively. This demonstrates the change of motion that occurred in the Paleocene (anomaly 31 to 24; Larson et al 1985; Patriat et al 1985; Royer et al 1988). This change of motion is particularly well recorded by the large offset northeast of Astrid Ridge ( $\sim 40 \mathrm{Ma}$ age offset). Such a change of motion will also match perfectly the extremities of the fracture zones lying immediately west of the Madagascar Plateau (northern flank) and Conrad Rise (southern flank). The Prince Edward FZ is therefore a recent feature (Middle Eocene, chron 20) and is not the continuation of the fracture zone running from Astrid Ridge.

Finally, new evidence about the early phase of opening of the Indian Ocean, from the Late Jurassic to the mid-Cretaceous, are found in the western part of the Enderby Basin. East of the fracture zone near Astrid Ridge, several parallel fracture zones are delineated in the deflection of the vertical charts. It shows that the direction of motion between Africa and Antarctica remained the same for $34 \mathrm{Ma}$, from chron M0(118 Ma) identified east of the Astrid Ridge (Bergh 1977, 1987) to chron 34 (84 Ma) located west of Conrad Rise (Bergh and Norton 1976; Patriat et al 1985). To the north, except for the Davie Ridge that records the relative motion between Africa and Madagascar, no fracture zone shows on the deflection of the vertical data: neither in the Mozambique Basin (Ségouffin 1978; Simpson et al 1979), nor in the western Somali Basin (Ségoufin and Patriat 1981; Rabinowitz et al 1983) or off the east African margin (Bunce and Molnar 1977; Cochran 1988). This is due to their north south orientation and to the very important thickness of sediments in these old basins. Along the western Australian margins, only the large offset Investigator FZ, the scarps of the Wallaby and Cuvier Plateaus, and the Naturaliste FZ that abuts the Naturaliste Plateau are visible. The possible curvature of the Investigator FZ into the Wallaby and Cuvier Plateau would be a direct evidence of the mid-Cretaceous oceanwide change in the plate motions.

Some linear and continuous features, not related to directions of relative motion, 
produce a typical signature on the horizontal gravity field. Among the most spectacular are the conjugate escarpments of Broken Ridge and the Kerguelen Plateau. These lines correspond to an offset of the basement along the Kerguelen Plateau (Coffin et al 1986) and to a deep linear trough along Broken Ridge (Fisher et al 1982). According to Mammerickx and Sandwell (1986), these topographic features are related to the demise of seafloor spreading in the Wharton Basin (Liu et al 1983; Geller et al 1983 ) and the initiation of spreading between the two plateaus (Mutter and Cande $1983)$ at chron $18-19(\sim 45 \mathrm{Ma})$. The match of these two curves provides a tight constraint upon the relative position of the Kerguelen Plateau and Broken Ridge prior to their break-up. The continent/ocean boundary mapped along the southern margin of Australia from magnetic and seismic evidence (Talwani et al 1979; Konig 1980; Veevers 1986) has a distinct and characteristic deflection of the vertical signature. We have used this criterion to identify the conjugate boundary along the Antarctic margin where the data are very limited. The deflection of the vertical signature also clearly outlines the limit of the continental shelf break (steepest gradient of the horizontal gravity field). Generally, this structural limit is well mapped from bathymetric data; however, around Antarctica where the data are sparse and scattered because of the remoteness and the ice-coverage, the altimery data now permit accurate delineation of the limit of the continental plateau. Another clearly visible feature is the change of topographic grain between the crust created along the Southwest Indian Ridge (at a slow spreading rate) and the crust created along the Southeast Indian Ridge and the Central Indian Ridge (at medium spreading rates). Actually, the age of this limit decreases towards the east, demonstrating the eastward propagation of the Southwest Indian Ridge (Patriat 1979; Tapscott et al 1980; Sclater et al 1981). Patriat (1987) mapped independently these two limits as the traces of the Indian Ocean triple junction respectively on the African and Antarctic plates.

\section{Conclusion: a revised tectonic summary diagram for the Indian Ocean}

Comparison of bathymetric data, deflection of the vertical lineations, and magnetic anomaly data permits the construction of a revised tectonic fabric chart for the Indian Ocean (figure 6). This chart is of significant value especially in the far southern ocean where new fracture zones have been identified and previously charted fracture zones extended. However, it is still only preliminary in nature as we have neither integrated the deflection of the vertical data with the actual topographic data to produce improved topographic charts (e.g. Driscoll et al., unpublished manuscript 1986) or repicked any magnetic anomalies. In addition, the geoid or gravity field of the oceans (Haxby 1985) contains very valuable information on the origin and structure of broad basic features of the ocean floor. The present study is the first step towards an international attempt to integrate all the above information, to provide some useful preliminary constraints for studies of the Indian Ocean tectonic history, and to show what can be accomplished by such integrated approach.

For the sake of clarity, we did not represent in figure 6 all the magnetic lineations that have been identified in the Indian Ocean; in particular for the Cenozoic, we have selected chron $34,33,31,28,24,20,18,13,6$ and 5 . The wealth of data accumulated in the Indian Ocean now represents as many constraints as one must reconcile in a consistent plate kinematic model. There are still some areas where data are lacking, 


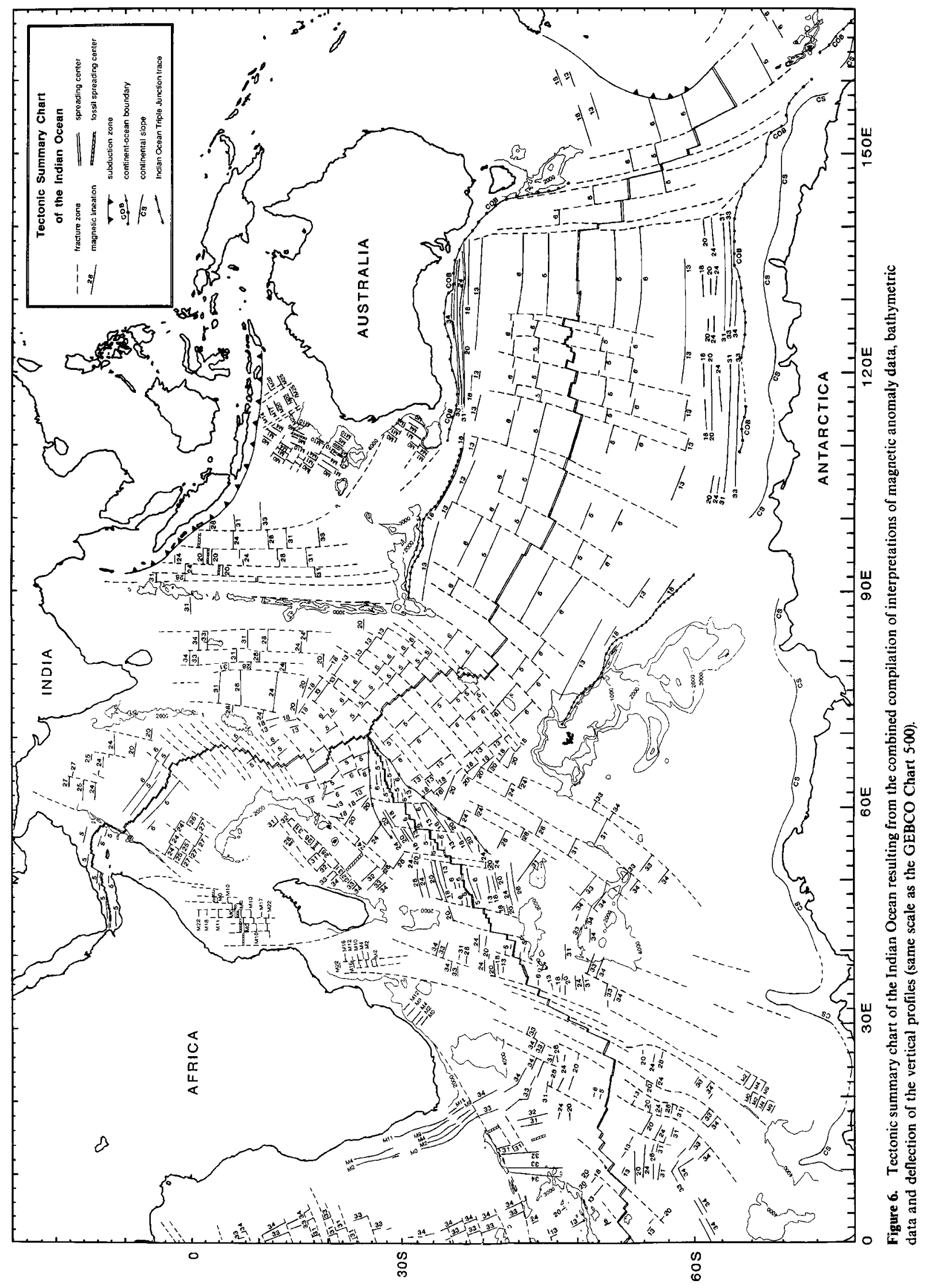


for instance, south of the Kerguelen Plateau in the Enderby Basin, in the vicinity of the Ninetyeast Ridge, in the Bengal Fan, in the Arabian Sea beneath the Indus Fan, in the region bounded by Chain Ridge, the Seychelles, the Mesozoic fracture zones in the western Somali Basin, and the adjacent Mascarene Basin. These areas mainly concern the mid-Cretaceous times when the plate boundaries reorganized (Cretaceous Quiet Zone). For this reason, no satisfactory model has yet been proposed to link consistently all the Mesozoic basins in the Indian Ocean, the South Atlantic and the Weddell Sea.

\section{Acknowledgements}

This work is part of a joint cooperative programme between the Institut de Physique du Globe de Strasbourg, the Institute for Geophysics at U.T. Austin (UTIG), the Lamont Doherty Geological Observatory, and the Scripps Institution of Oceanography. The authors wish to thank Robert L. Fisher for constructive comments on the manuscript. Help from Lisa Gahagan in completing the figures is greatly appreciated. This work was supported by NSF Grant OCE-86 17193 and by the sponsors of the Paleoceanographic Mapping Project (POMP) at the Institute for Geophysics, the University of Texas at Austin. UTIG contribution $\mathbf{n}^{\circ} 767$.

\section{References}

Bergh H W 1977 Mesozoic seafloor off Dronning Maud Land, Antarctica; Nature (London) 269 686-687

Bergh H W 1987 Underlying fracture zone nature of Astrid Ridge of Antarctica's Queen Maud Land; $J$. Geophys. Res. 92 475-484

Bergh H W and Norton I O 1976 Prince Edward fracture zone and the evolution of the Mozambique Basin; J. Geophys. Res. 81 5221-5239

Bunce, E T and Molnar P 1977 Seismic reflection profiling and basement topography in the Somali Basin: possible fracture zones between Madagascar and Africa; J. Geophys. Res. 82 5305-5311

Cande S C and Mutter J C 1982 A revised identification of the oldest sea-floor spreading anomalies between Australia and Antarctica; Earth Planet. Sci. Lett. 58 151-160

Cochran J 1988 The Somali Basin, Chain Ridge and the origin of the northern Somali Basin gravity and geoid low; J. Geophys. Res. 93 11985-12008

Coffin M F and Rabinowitz P D 1987 Reconstruction of Madagascar and Africa: evidence from the Davie Fracture Zone and western Somali Basin; J. Geophys. Res. 92 9385-9406

Coffin M F, Davies H L and Haxby W F 1986 Structure of the Kerguelen Plateau province from SEASAT altimetry and seismic reflection data; Nature (London) 324 134-136

Driscoll M L, Fisher R L and Parsons B 1986 Fracture zone trends and structure of the Souhtwest Indian Ridge: an investigation using Seasat altimetry and surface-ship bathymetry (unpublished manuscript)

Falconer R H K and Tharp M 1982 General Bathymetric Chart of the Oceans (GEBCO), sheet 5.14. Canadian Hydrographic Service, Ottawa, Canada

Fisher R L, Sclater J G and McKenzie D P 1971 Evolution of the Central Indian Ridge; Geol. Soc: Am. Bull. 82 553-562

Fisher R L, Jantsch M Z and Comer R L 1982 General Bathymetric Chart of the Oceans (GEBCO), sheet 5.9. Canadian Hydrographic Service, Ottawa, Canada

Fisher R L and Sclater J G 1983 Tectonic evolution of the Southwest Indian Ridge since the midCretaceous: plate motions and stability of the pole of Antarctica/Africa for at least $80 \mathrm{Ma}$; Geophys. J. R. Astron. Soc. 73 553-576

Gahagan L M, Royer J-Y, Scotese C R, Sandwell D T, Winn K, Tomlins R L, Ross M I, Newman J S, Müller D, Mayes C L, Lawver L A and Huebeck C E 1988 Tectonic fabric map of the ocean basins from 
satellite altimetry data. In Mesozoic and Cenozoic plate reconstructions (eds) $\mathbf{C} \mathbf{R}$ Scotese and W W Sager; Tectonophysics, 155 1 26

Geller C A, Weissel J K and Anderson R N 1983 Heat transfer and intraplate deformation in the central Indian Ocean; J. Geophys. Res. 88 1018 1032

Haxby W F 1985 Gravity field of World's oceans (color map). Lamont Doherty Geological Observatory of Columbia University, Palisades, NY

Hayes DE and Vogel M 1981 General Bathymetric Chart of the Oceans (GEBCO), sheet 5.13. Canadian Hydrographic Service, Ottawa, Canada

Heezen B C and Tharp M 1965 Physiographic diagram of the Indian Ocean (with descriptive sheet); Geol. Soc. Am. Inc. New York, NY

König M 1980 Geophysical investigations of the southern continental margin of Australia and the conjugate sector of East Antarctica. PhD. Thesis, Columbia University, New York, NY, $337 \mathrm{p}$

LaBrecque J L and Hayes D E 1979 Seafloor spreading history of the Agulhas Basin; Earth Planet. Sci. Letr. $45411-428$

LaBrecque J L and Rabinowitz P D 1981 General Bathymetric Chart of the Ocean (GEBCO), sheet 5.16. Canadian Hydrographic Service, Ottawa, Ca.lada

Larson R L, Mutter J C, Diebold J B and Carpenter G B 1979 Cuvier Basin: a product of ocean crust formation by Early Cretaceous rifting off Western Australia. Earth. Planet. Sci. Lett. 45 105-114

Larson R L, Pitman W C, Golovchenko X, Cande S C, Dewey J F, Haxby W F and LaBrecque J L, 1985 The Bedrock Geology of the World (color map), Freeman and $\mathrm{Co}$, New York, NY

Laughton A S, Whitmarsh R B and Jones M T 1970 The evolution of the Gulf of Aden; Philos. Trans. R. Soc. London A267 227-266

Laughton A S 1975 General Bathymetric Chart of the Oceans (GEBCO), sheet 5.5. Canadian Hydrographic Service, Ottawa, Canada

Lazarewicz A R and Schwank DC 1982 Detection of uncharted seamounts using satellite altimetry; Geophys. Res. Lett. 9 385-388

Le Pichon X and Heirtzler J R 1968 Magnetic anomalies in the Indian Ocean and sea-floor spreading; J. Geophys. Res. 73 2101-2117

Liu C S, Curray J R and McDonald J M 1983 New constraints on the tectonic evolution of the Eastern Indian Ocean; Earth Planet. Sci. Lett. $65331-342$

McAdoo D C and Sandwell D T 1985 Folding of the oceanic lithosphere; J. Geophys. Res. 90 8563-69

McKenzie D P and Sclater JG 1971 The evolution of the Indian Ocean since the Late Cretaceous; Geophys. J. R. Astron. Soc. 25 437-528

Mammerickx J and Sandwell D T 1986 Rifting of old oceanic lithosphere; J. Geophys. Res. 91 1975-88

Mark! R G 1974 Evidence for the breakup of Eastern Gondwanaland by the Early Cretaceous; Nature (London) 251 196-200

Mark1 R G 1978 Further evidence for the Early Cretaceous breakup of Gondwanaland off Southwestern Australia; Marine Geol. 26 41-48

Mayes C M, Sandwell D T and Lawver L A 1989 Tectonic history and new isochron chart of the South Pacific; J. Geophys. Res. in press

Monahan D, Falconer R H and Tharp M 1982 General Bathymetric Chart of the Oceans (GEBCO), sheet 5.10. Canadian Hydrographic Service, Ottawa, Canada

Mutter J C and Cande S C 1.983 The early opening between Broken Ridge and Kerguelen Plateau; Earth Planet. Sci. Lett. 65 369-376

Norton 10 and Sclater JG 1979 A model for the evolution of the Indian Ocean and the breakup of Gondwanaland; J. Geophys. Res. 84 6803-6830

Patriat P 1979 L'océan Indien occidental: la dorsale ouest-indienne; Mém. Mus. Nat. Hist. Nat. 43 49-52

Patriat P 1987 Reconstitution de l'évolution du systeme de dorsales de l'océan Indien par les méthodes de la cinématique des plaqques. Publ. by Territoire des Terres Australes et Antarctiques Françaises, Paris, $308 p$

Patriat P, Ségoufn J, Goslin J and Beuzart P 1985 Relative positions of Africa and Antarctica in the Upper Cretaceous: evidence for a non-stationary behaviour of fracture zones; Earth Planet. Sci. Lett. 75 204-214

Rabinowitz P D, Coffin M F and Falvey D 1983 The separation of Madagascar and Africa; Science, 220 $67-69$

Royer J-Y, Patriat P, Bergh $\mathbf{H}$ and Scotese C R 1988 Evolution of the Southwest Indian Ridge from the Late Cretaceous (anomaly 34) to the Middle Eocene (anomaly 20). In Mesozoic and Cenozoic plate reconstructions; Tectonophysics (eds) C R Scotese and W W Sager $155235-260$ 
Royer J-Y and Schlich R 1988 The Southeast Indian Ridge between the Rodriguez. Triple Junction and the Amsterdam and Saint-Paul Islands: detailed kinematics for the past $20 \mathrm{Ma}$; J. Geophys. Res. 93 13524-13550

Royer J Y and Sandwell D T 1989 Evolution of the eastern Indian Ocean since the Late Cretaceous: Constraints from GEOSAT altimetry; J. Geophys. Res. (in press)

Sandwell D T 1984 A detailed view of the South Pacific geoid from satellite altimetry; J. Geophys. Res. 89 1089-1104

Sandwell D T and Mc Adoo D C 1988 Marine gravity of the Southern Ocean and Antarctic Margin from GEOSAT: tectonic implications; J. Geophys. Res. 93 10389-10396

Schlich R 1975 Structure et âge de l'océan Indien occidental; Mém. hors série Soc. Géol. France. $6103 \mathrm{p}$

Schlich R 1982 The Indian Ocean: aseismic ridges, spreading centres and basins. In The Ocean Basins and Margins: the Indian Ocean (eds) A E Nairn and F G Stheli (New York: Plenum Press) 6 51-147

Schlich R and Patriat P 1971a Mise en évidence d’anomalies magnétiques axiales sur la banche oucst de la dorsale médio-indienne; C. R. Acad. Paris $\mathbf{B 2 7 2} 700-703$

Schlich $R$ and Patriat P 1971b Anomalies magnétiques de la branche est de la dorsale médio-indienne entre les îles Amsterdam et Kerguelen; C. R. Acad. Sci. Paris B272 773-776

Schlich R, Coffin M F, Munschy M, Stagg H M J, Li Z G and Revill K 1987 Bathymetric chart of the Kerguelen Plateau. Joint publication of the Bureau of Mineral Resource, Canberra, Australia, and the Institut de Physique du Globe, Strasbourg, France.

Sclater J G and Fisher R L 1974 Evolution of the east-central Indian Ocean, with emphasis on the tectonic setting of the Ninetyeast Ridge; Geol. Soc. Am. Bull. 85 683-702

Sclater J G, Luyendyk B P and Meinke L 1976a Magnetic lineations in the Southern part of the Central Indian Basin; Geol. Soc. Am. Bull. 87 371-378

Sclater, J G, Bowin C, Hey R, Hoskins H, Peirce J, Phillips J and Tapscott C 1976b The Bouvet triple junction; J. Geophys. Res. 81 1857-1869

Sclater J G, Fisher R L, Patriat P, Tapscott C and Parsons B 1981 Eocene to recent development of the Southwest Indian Ridge, a consequence of the evolution of the Indian Ocean triple junction; Geophys. $J$. R. Astron. Soc. 64 587--604

Ségoufin J 1978 Anomalies magnétiquẹs mesozoiques dans le bassin de Mozambique; C. R. Ac. Sci. Paris B287 109-112

Ségoufin J and Patriat P 1980 Existence d'anomalies mésozoiques dans le bassin de Somalie. Implications pour les relations Afrique-Antarctique-Madagascar; $C$. $R$. Accd. Sci. Paris, B291 85-88

Ségoufin J and Patriat P 1981 Reconstructionns de l'océan Indien occidental pour les époques des anomalies M21, M2 et 34. Paléoposition de Madagascar; Bull. Soc. Géol. France, 23 693-707

Simpson E S W, Sclater J G, Parsons B, Norton I O and Meinke L 1979 Mesozoic magnetic lineations in the Mozambique Basin; Earth Planet. Sci. Lett. 43 260-264

Talwani M, Mutter J, Houtz R and König M 1979 The crustal structure and evolution of the area underlying the magnetic quiet zone on the margin south of Australia. In Geological and geophysical investigations of the continental margins; Am. Assoc. Pet. Geol. Mem. (eds) Watkins, Montadert and Dickerson $29151-175$

Tapley B D, Born G H and Park M E 1982 The SEASAT alimeter data and its accuracy assessment; $J$. Geophys. Res. 87 3179-3188

Tapscott C, Patriat P, Fisher R L, Sclater J G, Hoskins H, and Parsons B, 1980 The Indian Ocean triple junction; J. Geophys. Res. 85 4723-4739

Udintsev G B, Fisher R L, Kanaev V F, Laughton A S, Simpson E S W and Zhiv D I, 1975 Geologicalgeophysical atlas of the Indian Ocean. Academy of Sciences of the U.S.S.R., Moscow, $151 \mathrm{p}$

Veevers J J 1986 Breakup of Australia and Antarctica estimated as mid-Cretaceous $(95 \pm 5 \mathrm{Ma})$ from magnetic and seismic data at the continental margin; Earth Planet. Sci. Lett. 77 91-99

Veevers J J, Tayton J W, Johnson B D and Hansen L 1985 Magnetic expression of the continent-ocean boundary between the western margin of Australia and the Eastern Indian Ocean; J. Geophys. 56 $106-120$

Vogt P R, Cherkis N Z and Morgan G A 1983 Project Investigator I: evolution of the Australia-Antarctic disordance deduced from a detailed aeromagnetic survey. In Antarctic Earth Science, Proceeding of the IV International Symposium on Antarctic Earth Science (eds) R L Oliver, P R James and J B Logo (Canberra: Australian Academy Press) 608-613

Weissel J K and Hayes D E 1972 Magnetic anomalies in the Southeast Indian Ocean. In Antarctic Oceanology II: The Australian-New Zealand sector Am. Geophys. Un. Ant. Res. Ser. (ed.) D E Hayes $19165-196$ 
Weissel J K, Anderson R N and Geller C A 1980 Deformation of the Indo-Australian plate; Nature (London) 287 284-291

Whitmarsh R B 1974 Some aspects of the plate tectonics in the Arabian Sea. In Initial reports of the Deep Sea Drilling Project 23 527-535 